Meta

Journal des tradlucteurs

Translators' Journal

\title{
The Translation of Authoritative Statements: a Discussion
}

\section{Peter Newmark}

Volume 27, numéro 4, décembre 1982

URI : https://id.erudit.org/iderudit/003728ar

DOI : https://doi.org/10.7202/003728ar

Aller au sommaire du numéro

Éditeur(s)

Les Presses de l'Université de Montréal

ISSN

0026-0452 (imprimé)

1492-1421 (numérique)

Découvrir la revue

Citer cet article

Newmark, P. (1982). The Translation of Authoritative Statements: a Discussion. Meta, 27(4), 375-391. https://doi.org/10.7202/003728ar d'utilisation que vous pouvez consulter en ligne.

https://apropos.erudit.org/fr/usagers/politique-dutilisation/ 


\section{THE TRANSLATION OF AUTHORITATIVE STATEMENTS : A DISCUSSION}

Peter Newmark

I define authoritative statements as non-literary texts which derive a large measure of their authority either from the political, social or academic status of their authors and/or from the high quality of their writing. All official, administrative and legal texts - where each proposition is a 'performance' or a 'speech act' an indication of action to be taken - come within this field. Political, philosophical, sociological, psychological, scientific, technological, historical texts are only included if they are by authors whose word is 'law' in the field concerned, or if they are well written in the sense that the language closely and succinctly embraces thought which itself closely embraces reality, that "proper words are used in proper places". The translator is qualified and has to make this assessment since he is engaged in the same practice. He not only has to be sensitive to and a critic of language; he also has to write well himself.

From a translator's point of view, authoritative statements resemble serious literary works in demanding close attention to the two main and equally important articulations of meaning, the word and the sentence, where the effort to reconcile word, sentence and finally text and make them cohere requires continuous compromise and readjustment. However, whilst the writer of serious literature may be writing to express his personality, authoritative statements are addressed primarily to their readers, and must be comprehensible to them, unless they are written in an autocratic state. And whilst the translator of an authoritative national statement is not directly addressing the second reader who is, as it were, listening in (in 'international' statements on the other hand, whether of law, administration or philosophy the second reader is as important as the first), authoritative statements are likely to be stylistically less idiosyncratic than is serious literature: metaphors less prominent, vocabulary more formal and abstract, grammar more conventional except when they are written by outstanding personalities. Further, the facts, not being embedded as symbols in allegories, must solicit the translator's attention as much as the manner of expression.

The language of authoritative statements is likely to be literal and denotative, except where it is enforced by emotive appeal: "I have nothing to offer 
but blood, toil, tears and sweat"'Je n'ai à vous offrir que du sang, du travail, des larmes, de la sueur (the three metonyms or metaphors are both literal and figurative). A stock metaphor can be translated conventionally: "The wind of change is blowing" (Harold MacMillan) Un grand courant d'air frais souffle (Collins - Robert Dictionary translation) but an original metaphor, "the underbelly of the Axis", must be preserved as le bas - ventre de l'Axe, der Unterbauch der Achse rather than the conventional point vulnérable, der wunde Punkt.

Consider also Roosevelt's acceptance speech of 1932, where a metaphor has recently become a metonym: "Then came the crash... Translate that into human terms". Both French and German adopt the same word: Puis vint le krach. Traduisez ça en termes humains - Dann kam der Krach... Übertragen Sie also (man übersetze?) das in menschliche Worte - "We must lay hold of the fact that..." Wir müssen die Tatsache ergreifen, dass... Nous devons saisir le fait que (Note that French can sometimes be as 'sensorial' and 'visual' as English or German).

Further, the element of self-expression in authoritative statements is not the essence of its intention, but the translator has to pay the same respect to bizarreries of idiolect as in fantastic literature: La France y voit un renfort décisif de notre latinité à l'avantage de tous les hommes. 'France sees it as a decisive strengthening of our Latinity which benefits all mankind'. (De Gaulle)

I am assuming that authoritative statements are normally to be translated by the 'semantic' method of translation: that is, the translator must render, in as far as the syntactic and associative constraints of the target language allow, the precise contextual meaning of the original text. I assume that as the SL text is efficiently written and is addressed specifically to SL readers, the translator will not have to adapt the text for TL readers; the text will more or less remain within the SL culture, unless it is an 'international' text relating to an international organization.

I propose now to discuss the translation of linguistic features which these texts have in common.

II

The grammatical structures of authoritative statements are likely to be more formal than other types of statements, although one must bear in mind the general tendency to move from formal to informal educated language since at least the Second World War. (Consider the change in the language of The Times, of American Presidents, of dictionaries and instructions, etc.). Grammatical equivalents are always closer in formal than in informal texts, which have idioms and 'alternative' common words (mec, nana, fringues, binette, etc., with an extra pragmatic charge). Take the first paragraph of Kant's Kritik der reinen Vernunft :

1. Dass alle unsere Erkenntnis mit der Erfahrung

2. That all our knowledge begins with experience

3. There can be no doubt that all our knowledge

1. anfange daran ist gar kein Zweifel; denn

2. there can be no doubt. For

3. begins with experience. For 
1. wodurch sollte das Erkenntnisvermögen sonst

2. how is it possible that the faculty of cognition

3. how should our faculty of knowledge

1. zur Ausübung erweckt werden, geschähe es

2. should be awakened into exercise otherwise

3. be awakened into action did not

1. nicht durch Gegenstände, die unsere Sinne

2. than by means of objects which affect our

3. objects affect our senses

1. rühren und teils von selbst Vorstellungen

2. senses, and partly of themselves produce

3. partly of themselves produce

1. bewirken, teils unsere Verstandestätigkeit

2. representations, partly rouse our powers of

3. representations, partly arouse the activity

1. in Bewegung bringen, diese vergleichen, sie

2. understanding into activity, to compare to

3. of our understanding to compare these representations

1. zu verknïpfen oder zu trennen, und so den

2. connect, or to separate these, and so to

3. and by combining or separating them

1. rohen Stoff sinnlicher Eindrücke zu einer

2 . convert the raw material of our sensuous impressions

3. work up the raw material of the sensible impressions

1. Erkenntnis der Gegenstände zu verarbeiten,

2 . into a knowledge of objects, which is called

3. into that knowledge of objects which is called

1. die Erfahrung heisst? Der Zeit nach geht

2. experience? In respect of time, therefore

3. experience? In the order of time, therefore,

1. also keine Erkenntnis in uns vor der

2. no knowledge of ours is antecedent

3. we have no knowledge antecedent to experience

1. Erfahrung vorher, und, mit dieser fängt alle an.

2. to experience but begins with it. (J.M. Meiklejohn, 1854)

3 . and with experience all our knowledge begins. (N. Kemp Smith, 1929).

Grammatically, Meiklejohn and Kemp Smith (not to mention Max Müller) operate the standard and rather similar transpositions (main clause for main clause, adjectival clause for participial phrase, etc.), the main differences between the two translators being the decision whether or not to deviate from Kant's emphasis, and therefore in general his word-order. Additionally, one would expect any German - to - English translator to "restate the content of the more complex sentences in a number of separate sentences" (Kemp Smith) since the German academic style, modelled as it is on Latin, favours longer sentences than English, including active and passive participial phrases. When Kemp Smith states that Kant "inserted clauses into sentences that were not suited for their reception", and "crowds so much into each sentence... makes unclue use of parenthesis" he is giving notice of his intention to interpret the 
text, at the same time rendering it easier to read than the original, but as a criticism of Kant his remarks are high-handed.

In general, synthetic and semi-synthetic languages are not difficult to translate grammatically into English, since through contrastive linguistics one can work out a large number of typical transpositions. The lexical exchange between philosophical German and English (the latter draws its intellectual semantic fields mainly from French and Latin) is more difficult, particularly where there is a possible conflict between words heavy with philosophical tradition ('cognition') and the more recent informal approach to language ('knowledge'). In general the philosophical translator should not let himself be weighed down by tradition, since he is addressing new classes of readers but should concentrate on 'clean' words and the kind of rhythmic emphasis which Nowell Smith gives to the last sentence quoted.

The closer an authoritative statement is to an official and formal style, the fewer problems are likely in the translation of its syntax. Lexical problems increase all the time, but syntactic innovations in any language are rare (in English, the increasing use of gerunds to replace infinitives? e.g. 'opportunity of enjoying' rather than 'opportunity to enjoy'). Sentences such as : La France et l'Espagne sont les seuls pays membres qui ont adopté une interdiction générale du refus de vendre. De nombreux pays membres ont choisi une attitude juridique plus nuancée qui consiste à limiter l'interdiction du refus de vendre à quelques cas particuliers dans lesquels il apparaît clairement que le refus de vendre présente une certaine gravité "Only two member countries, France and Spain, have adopted a general prohibition to sell. Many Member countries, on the contrary, have chosen to adopt a less severe legal attitude which consists in limiting the prohibition of refusal to sell to a few specific cases in which it is clearly apparent that refusal to sell is a serious matter" (Refusal to Sell OECD) can be translated without difficulty. Here the connector 'on the contrary' is the translator's only 'intervention'.

The translator only has to bear in mind the English tendency to emphasize without using adjectival clauses, to promote gerunds, to replace SL verbs of equivalence ('consist of', 'appears', 'include', 'represent', etc.) with 'be' or 'have'. The lexical problems (e.g. nuancé) are not so straight-forward.

The translator has to bear in mind some of the general findings of contrastive syntax, e.g., English preference for participial phrases where French has adjectival clauses and German uses noun groups encapsulating participles. Clarity, explicitness and the preservation of emphases are the most important principles.

At the other end of the scale where the style is informal and personal a bald concise statement: Mon inspection est agitée (De Gaulle) has to be expanded : 'My tour of inspection was a turbulent one' (T. Kilmarten).

III

"It was much more than a simple portrait - I had to understand the nation's visual image of a much loved Royal personage" (Observer, p. 60 20.7.80). 
It is arguable (but controversial) that serious imaginative literature is selfcontained, can only be explained through itself, and that its background can mislead as an interpretation - "trust the tale not the teller" (D. H. Lawrence). The same cannot be said of authoritative statements, which by definition derive their authority from the relation between the writer and his readers, the official and his public, the speaker and his audience, as well as the occasion of the statement. The fact that an authoritative statement by a great philosopher or statesman may also have an independent and permanent value cannot dispense the translator from a thorough investigation of the value of the most significant concepts, the theme-words in the text, which may be verified in the author's writing generally, in the received understanding of the eventual readers, and the occasion of the statement. It is here, in the important words, that a translation has to show least loss of meaning. (It is notable that such "lexicographers" as Alan Bullock, Raymond Williams, Edward de Bono, Charles Rycroft, Geoffrey Payton have fairly recently published useful critical dictionaries of these Stichwörter or key-terms). If I now consider the translation of various categories of key-terms, I distinguish also three types of meaning: (1) semantic meaning, the meaning arising from the text read as a self-contained piece of language (2) pragmatic meaning, meaning related to intention and use - i.e. the purpose of the SL text playing on the attitude of the readers (3) semiotic meaning, the full meaning, taking into account the motive of the author, his personal use of the key-term, the place of the SL text in a tradition, if any, and a perspective on the objective truth of the statement.

Theme words denoting the subject and the significant concepts of the SL text must be identified by the translator, and if they have no precise equivalents in the TL, they should be componentially analyzed at the first citation and then identified by a translation label. Thus Kant's Vernunft may be labelled as 'reason', but it is closer to the 'use of reason', to 'common sense' to 'reasonable behaviour' and has not the intellectual, rational, logical element which is centred in the German word Ratio. Again la contestation could be labelled as "contestation' (at present a 'dictionary word', i.e. only found in dictionaries) in inverted commas until the translator thinks it is accepted, when he discreetly drops the inverted commas and defined as a rejection of the dominant class ideology or of the 'Establishment', but the same word should be kept throughout the text, like other SL theme-words which come within the interstices of the target language. Most theme-words in Pascal, such as misère, amour-propre, force probante can be satisfactorily accounted for by single words : 'wretchedness', 'selflove', 'demonstrative power'. In modern philosophy, there are examples of concepts identified with one philosopher, either in a special sense or because they are not readily translatable, which are usually transferred. One remembers Bergson's élan vital, 'vital impulse', 'life force' (Shaw's adaptation); Heidegger's Dasein, das Man (Heidegger in fact coined at least 100 new complex words ending in '-being', and used many German words in his own sense, developing "his own German, his own Greek and his own kind of etymologies") (Naess, 1974); Sartre's néant; Lévi-Strauss' bricolage. 
In all such cases, the importance of the concept, the neatness of equivalence, the argument for clarity and avoiding cultural snobbery are points favouring translation, whilst the unique use of the word made by the author in translation, awkwardness in fitting the word syntactically, or the link between the concept and the author, suggesting that the concept will remain 'provincial' and tied to its period, argue in favour of transcription (or transference). In any case, in a scholarly or a 'decent' translation, the translator should transcribe, translate if necessary with a label, and give a careful definition or componential analysis. In further references, he is likely to use the transcribed term if it is already current; if not, he should 'push' the translated term, provided its special restricted sense is not likely to be confused with its general sense.

In my opinion, it is not sufficient for the translator simply to provide a brief 'key' for his theme-words. The sociologist W.G. Runciman in his introduction to Weber (1978) commenting on Eric Williams' translation of Weber's main works states that Betrieb is throughout translated as 'enterprise', Unternehmung 'undertaking' : the distinctions out of context are virtually meaningless, and since the implication is that the German terms are used in the same sense consistently, this would appear to be the right place to define and contrast the two terms, rather than to rely on the various contextual citations. (It becomes increasingly difficult to insist that extra-contextual definition is meaningful and useful). Further, Stand is translated as 'status group', a (legitimate) translation label that has to be defined, Duma, a recognized term, is rightly transcribed without explanation; decuriones is simply translated as 'municipal councillors', (without a transcription) on the translator's legitimate, not necessarily correct assumption (as I presume - it is not stated) that the non-classically educated English reader will have less interest in Roman society than the German. I tend to assume that in 'communicative' translation (Newmark, 1981) anything in the SL text that is obviously of no interest to the TL reader can be deleted. Weber appears to be a difficult case; his translators admit that he writes well, but that his is a 'gothic castle' style, written for the eye rather than the ear, synchronizing rather than serializing his ideas. Therefore they have broken up the grammar but retained Weber's images and terms, i.e. translated the grammar 'communicatively' recasting it, and the lexis 'semantically'. I cannot say how successfully they have done it, but the aim is perfectly legitimate, particularly if one assumes that Weber's ideas and concepts are authoritative (e.g. Verstehen is 'interpretive understanding') but that his syntactic style forms part of a rather petrified German literary tradition which a translator need not regard as 'sacrosanct'.

In the definition and interpretation of key-terms the translation of authoratitative statements comes closest to that of legal texts. Legal language, as Baldinger (1980) has said, attempts to draw precise frontiers to the meanings of ordinary words. Easy enough to define terms of art such as 'felony' and 'tort' - the difficulty is to define, and then translate Angestellter (an employee 'seated when at work'), Führungskräfte ('top policy directors') Ermessen 'free appreciation' Beamter (non-existent in the GDR). Where even in legal language a concept is recognized as indeterminate, one distinguishes between its hard Begriffskern 
('conceptual nucleus', or primary meaning) and its Begriffshof ('periphery') which is vague and may fluctuate at its rim with each new significant use.

The closer a key-term draws to a legal term (I instance words such as 'authority', 'law', 'offence') the more inadequate a translation without both transference and a definition becomes. Thus no thesis on Staatsanwaltschaft could be translated without a close comparison between the functions and office of a Staatsanwalt and a public prosecutor. Whether in translation or in original writing, a paper on a country's institutions transfers a higher proportion of legal than of any other type of institutional terms, but an officially translated law or an international treaty must not use transferred or 'borrowed' terms.

If a theme-word is used in more than one target-language sense, it has to be translated by the appropriate word at each citation. The writer may use the same theme-word both generically and in narrower senses in one passage, and here the translator has to distinguish the various senses. Thus in Lanson's famous description of l'esprit français, 'the French mind' which analyzes the French personality, the translator is I think justified in rendering esprit mondain 'wordly wit', esprit sans épithète, 'esprit without qualification' (Ritchie, 1952) esprit gaulois 'Gallic character', esprit d'analyse 'spirit of analysis' thus he uses five different words - a single word would be impossible. Again, Freud's Der Witz, first wrongly translated as 'Wit', now has the authorized title Jokes, but is 'wit' in a few appropriate cases in the book. Scherz (a joke arising in play) is translated as 'jest', although this word is losing currency. A translator continually has to weigh accurate rendering of meaning against equal frequency of usage in translating lexical units, syntactic structure or 'emphatic' wordorder.

Further, there is a case for alternative TL versions of an SL theme word, if they are used to cover two aspects of the same concept. Thus in Lévi-Strauss' La Pensée Sauvage, there is a passage on understanding a work of art by examining a reduced version of it, which is compared to the way that Clouet looked at nature as a miniaturist. The theme-word, modèle réduit is translated both as 'miniature' and 'small-scale model'. Thus the translator exploits what Hilary Putnam (1978) has called "the division of linguistic labour" by using two referential synonyms for the one 'object' for the purpose of encompassing both the theme (appreciation of work of art) and the comparison (with Clouet's miniatures). (The translator takes two bites at the same cherry). The device is useful provided that the link between the referential synonyms is clear.

\section{IV}

The above examples of theme-words have been relatively simple. They assume a homogeneous cultural background, where the theme-word has a personal or a representative meaning. There are more complicated cases where an important term is used like a tennis ball, the victim of conflicting societies, intellectual attitudes, as well as personal interpretations. Skinner (1980) instances 'civil', 'native', 'patriot', 'myth', 'liberal', 'gentleman', 'black'. Here it may be necessary for the translator to show not only the particular sense given to the 
term by the SL writer, but to show how this sense differs from other 'relevant' senses.

Instance the following quotation: "The Shah was a true friend of the West" (Henry Kissinger on hearing of the death of the Shah of Persia, 27.7.80).

There appears to be no difficulty in translating the above sentence into French or German but in GDR German 'the West' might well be glossed. Nevertheless, since the word 'West' is a metaphor that can have many different interpretations, I think that the translator may have to interpret it if he is to produce an adequate translation. The translator has to indicate the general differences in interpretation by the media (and the media dictate the accepted public metaphors in 1980) in the capitalist, socialist and third world countries; where "the West" may mean "the free world" (freedom of speech and opinion?), "the capitalist countries" (the exploitation of the majority by a small minority?) and "the developed countries" (continued impoverishment of the poorer countries?) respectively. The translator may have to point out the three interpretations, adding that in this context "the free world" is the most likely interpretation, and that as Henry Kissinger was U.S. National Security Adviser and Secretary of State during a considerable period of the Shah's reign, "the West" should additionally be identified with the Republican Party's prevailing concept of US political and economic interests at that time. Where possible, the translator has to examine the contextual mentions of 'the West' in Kissinger's speeches and books. Note that there is no question here of the translator criticizing the concept - no infringement of human rights is implied - directly, but he has to be prepared to give an adequate explanation of any metaphor. Further, the expression 'true friend' suggests the idea of giving valuable support and has an approving ('purr') connotation.

Up to now the phrase has been considered mainly in relation to its authorship and the SL culture. If we now consider it in relation to the reader, the West is recognized as the non-socialist part of Europe ('flee to the West') or as the area of the NATO countries. There is therefore no difficulty about a 'literal' translation, but it is inadequate if the reader is to understand Kissinger's as an authoritative statement. Therefore if the translated statement is to be reproduced or quoted in a book, an annotation is required. Needless to say any reduction of metaphor to sense, such as is entailed here, has a subjective element, but the reader has to be made aware of the variable components in the sense of interpretations of any stock metaphor, which always exist.

There is an arbitrary element in equating the meaning of any stock metaphor with another: thus in De Gaulle: du haut de l'État: 'from the pinnacle of the State', English has the additional sense of 'risk'.

Token words, Matoré's (1953) mots-témoins are the words that typify a fact of civilization, that characterize a region or a period. Many of the words cited by Matore for the early 19th Century, such as commis, rayon, facture, négociant, client, employé, épicier are now translated except when they are used to provide local colour. Words like épicier and 'grocer' may become as remote 
pre-supermarket token-words as mercier, 'haberdasher'. Note that words such as 'capitalist', 'bourgeois', 'bureaucratic', which appear to originate as token words of fact rather than value, acquire ameliorative or pejorative values and then later are reestablished as social facts ('bourgeois society', 'the socialist countries') without hostile connotations in the minds of their protagonists or opponents who select previously factual words to express extreme hatred 'imperialism', 'fascism', 'communism'.

The translator is naturally inclined to transcribe token-words since they are culturally bound and produce local colour. Thus a translation of any of the French Annales historians such as Braudel or Le Roy Ladurie retains many SL words, often adding a translation or explanation where appropriate (Ostsiedlung, the 'Germanic colonization of eastern lands', 'menudi', 'minor foods') whilst the British historian Richard Cobb (l'étonnant Cobb) uses French profusely to convey intimacy as well as local colour. In a reasonably serious work it appears to me to be logical to transfer the word for at least any material or institutional product of the SL culture, provided it is likely to remain within that culture; often a difficult decision, given the influences of vogue-snobbery and commercial interests, the special chic of using a foreign word or an obviously translated collocation (domaine, château, clos, bouquet, chambré, brut, remuage, dégorgement, appellation contrôlée).

There are few lexical words in any one person's active vocabulary which have not, if only unconsciously, a favourable or an unfavourable connotation for him; few words are 'psycho-linguistically' value-free. However, a translator would not normally be worried by connotational difficulties in the translation of common words in one person's statement, unless one or two were frequently repeated (suggesting a preference or fixation) and where the repetition and stress within the TL sentence would have to be preserved.

However, when considering words which 'sociolinguistically' express moral value-judgements, the translation problem is in principle, more difficult than in the case of the 'event', 'object' or 'fact' words that make up 'informative' texts.

Such words are of three types: (1) patently 'disaster' or 'bliss' words, favourable or unfavourable words such as Elend, Glück, félicité, misère. A glance at these show they have rather less than close one to one equivalents in foreign languages, and the temptation to transfer them which has to be resisted is sometimes strong. The degree of intensity and of material or mental emphasis in these words are not easy to assess and mediate into another language, (2) Hayakawa's (1975) 'purr' and 'snarl' words, the words that 'reveal states of mind, not facts or conditions in the extensional world". Where such words appear in authoritative statements, they have to be literally translated. Their vacuous content may not affect the TL reader as potently as they arose from the SL writer. Thus Hayakawa instances 'Reds', 'radicals', 'filthy scum', 'greedy monopolists' as snarl words, and 'the sweetest girl in the world' and 'poetry as the breath and finer spirit of all knowledge' (Wordsworth) as purr 
expressions. On the whole one wouldn't expect to find such language in authoritative statements, and it might occasion the translator's footnotes to mark prejudice rather than an elaborate mimesis of their strong or hard effect. When words such as 'fascist', 'imperialism', 'totalitarianism' are used by politicians and statesmen in an emotive sense, they are normally understood by the SL listener, and the translator would have to gloss them if the terms were misleading. Thus the Federal German government was referred to by Honecker as an 'imperialist power' at the height of the Polish crisis, and the translator could perhaps point out in a footnote that this government was not trying to extend its territorial rule. (3) Words that have a primarily cognitive meaning but which in their current sense have either a positive or a negative connotation. These words have four translation applications.

First, the translator has to see that such words are not inappropriately collocated: une tumeur can be favorisée ('developed') but not "favoured"; a 'pleasant surprise' can be 'sudden' but not brutal; 'pleasant things' may be überraschend but not befremdend or verblüffend. Secondly, a translator has to be careful to translate words like modique, ('meagre' or 'modest') terrible ('terrific, marvellous' or 'terrible') inélégant, ('ungainly', 'rude') suffisant ('satisfactory' or 'pretentious'), discret, 'slight' but discreto (It.) 'sizeable, considerable', formidable, 'competent', 'fair', 'average', etc. in their appropriate ameliorative, pejorative or neutral sense. Thirdly, capitalist and Marxist ideology may describe the same object with a purr or snarl term. ('Bandit' or 'freedomfighter', Fluchthelfer or Menschenhändler (Lewis (1979) etc.). Lastly, both positive and negative concepts may have different meanings in the two ideologies : 'freedom' may be 'freedom of speech and opinion' or 'the right to employment'; 'democracy' may be pluralistic, including rights for minorities or merely the carrying out of a majority decision; 'fascism' may be 'totalitarian dictatorship' or 'the last stage of capitalism' or an Italian type corporatist state (cf. 'exploit', 'profit', 'agitation', parteilich, régime). The translator has to be sensitive to evaluative language or evaluative implications. Slight divergencies between the original and the translation of Braudel's Capitalism and Material Society showed the translator to be less critical of capitalism than the author.

\section{VII}

I use 'stylistic markers' in the sense of certain repeated words or phrases that indicate a writer's focus of thought, and therefore his preoccupations; whilst these are more characteristic of creative literature than of authoritative statements, the principle that any stylistic marker which is frequently repeated in the SL text should be correspondingly repeated in the TL text is valid, and should only be replaced by an 'elegant variation' if the instance is careless or trivial. Stalin's war-time phrase 'it is well known' (izvestno) for what wasn't is an example. Churchill's Edwardian use of 'pray' being deliberately archaizing is difficult to translate. Ralph Manheim (1978) has pointed out that Hitler's stylistic markers lie as much in his 'senseless' use of the German enclitics ja, schon, eigentlich, eben, geradezu, wohl, denn, schon, noch as in his use of superlatives and of coarse language. However, these enclitics are not 'senseless'; 
they are phatic, assuming the reader's agreement, flattering him with the idea that a proposition is clear to himself and the author but not to the ignorant outsider. English has not got the same variety of enclitics; (which are often not translated). The nearest English equivalents, 'of course', 'clearly', 'in fact', are more 'lexical' (less phatic) than the German or Italian, but again, when used as stylistic markers, they become more significant than in their normal use, (cf. the vestigial repeated use of 'you know' expressing nervousness or the attempt to gain time to reflect (cf. vous savez).) In written statements, repeated use of 'it is an interesting fact that', 'of course', 'significantly' have to be as carefully translated as ironical markers such as 'seemingly'.

\section{VIII}

I have written in detail elsewhere (Newmark, 1981) about methods and criteria for translating institutional terms. Since I am writing here of authoritative statements, it is appropriate to suggest that governments should issue lists/glossaries of official translations of terms for their own main institutions and bodies, taking the advice of native translators for each country. The translation of terms such as aménagement du territoire (town and country planning, national and regional development, regional improvement), H.L.M., promotion sociale, comité d'entreprise (labour-management committee, joint production committee, works-council), etc. has never yet been settled. At present, even reputable bilingual dictionaries include amateurish translations that carry no authority, for many institutional terms. The Standard translations of some national legal and administrative terms (juge d'instruction, tribunal de grande instance) some of which have been long debated, are particularly required, and could be issued by embassy press bureaux.

IX

One problem in translating public speeches bears on the difference between the spoken and the written word - the spoken word suggests the person, the attempt to recreate a personality, as against the written word, which emphasizes the facts and the 'straight' meaning. Here there are two kinds of translation, both accurate. Is a sentence such as En un siècle, de multiples interventions, sommations, expéditions, invasions, européennes, américaines, japonaises valurent à la Chine autant d'humiliations et de démembrements to be translated as "In one century, numerous interventions, summonses, expeditions, invasions - European, American, Japanese - cost China as many humiliations and territorial disruptions" or as "In one century, Europe, America and Japan humiliated and dismembered China with all their summonses, expeditions and invasions' (since interventions, lui valurent and autant de are virtually redundant). The first translation, which would normally be preferred, follows De Gaulle's emphases and is closer to what he said; the second transfers the sentence to a reporting style and reproduces the facts as forcibly, but not as idiosyncratically.

The difference between 'documentary' and 'representational' translation can also be illustrated in the way the translator renders the kind of stock metaphor where the image remains more or less present in the mind. Thus : La Fran- 
ce épouse son temps may be 'adapts to', 'accepts' (documentary) or 'is wedded to', 'embraces' (representational); excédent de berceaux sur tombeaux: 'higher number of birth than death rate' or 'excess or cradles over graves'. Again: $I l$ ne faut pas s'attendre à ce que les professionnels de la nostalgie, du dénigrement, de l'aigreur, renoncent, tout au moins pour le moment, à suer le fiel, à cracher la bile et à lâcher le vinaigre. Here the French Embassy translation in New York: "We cannot expect the professional dealers in nostalgia, denigration and bitterness to give up, at least for the moment, venting their spleen, spitting out their bile, distilling their vinegar."

The problem, the basic problem of all translation, is the metaphors. One can't 'sweat gall' or 'release vinegar'. The above translation reproduces fairly closely the degree of originality or unusualness of the collocations, though it falls short of the possible violence of lacher le vinaigre, 'discharging their sourness'. (The originality lies in the collocations, not in the metaphors, and the vinaigre image can therefore be replaced). However, the 'documentary' translation of the three idioms might be! 'venting their anger, peevishness and sourness' thus reducing the figurative element.

The extracts illustrate the difficulty of translating significant spoken statements of policy made in an exceptionally personal way. Which is the more important? The man or the facts? To what extent should the repetitions of which De Gaulle was so fond 'travel' into another language? As I see it, they have to. What does a translator do with: Nous devons rester un grand peuple rassemblé. Depuis quatre ans, en dépit des orages, c'est au fond, ce que nous sommes. $Y$ ont trouvé leur compte, la justice et l'efficacité. 'We must remain a great people gathered together. For the past four years, in spite of the storms this is basically what we have been. Thereby justice and efficiency have benefited'? In the last sentence, the officialese style, verb (V) - object (O) - subject (S), the inverted word order as well as the personifications give the subject exceptional stress, indicating the weight and the symbolism of the two concepts. Much as I would like to translate "Thereby have received their due - justice and efficiency" the English will not (yet) stand this word order, though the inversion creates no obscurity, and with the European influence, may later become acceptable. Intuitively, SVO is a natural word-order, whilst the displacing of the subject to the end puts it as a stress at the peak of a crescendo. The translator should where possible follow the natural stresses of word-order although he cannot get over the artificial blocks (notably putting the lexical component of a composite tense at the end of the sentence) imposed by the scribes for say Latin and German.

For repetitions, the translator normally has to follow the speaker even if some languages favour them rather more than others: Les chagrins sont des chagrins; les difficultés sont les difficultés. Mais la France est la France et il faut la servir', 'Disappointments are disappointments; difficulties are always difficulties. But France is France and we must serve her'. The repetitions, like other aspects of linguistic "transfer" or interference, may sound strange at first, but like strange music, they persuade after several readings. One may want to deviate from the original but a 'recall to order' to the principles of strict 
translation supported by the 'back translation test' brings one back. In the above passage the second 'les difficultés' is tentatively rendered by 'always difficulties', suggesting the article is there for greater stress.

André Passeron (1966) has composed a glossary of Gaullist phrases where the image has to be preserved in translation, even where the phrase is adapted and part of the sound-effect (which may suggest irony as well as force) is lost. Thus aréopage technocratique (negative sense) 'an areopagus or high court of technocrats', inaugurer les chrysanthèmes 'open a chrysanthemum show', (negative) cordiale virtualité 'potential of warm friendship, cordiality (positive) 'diable dans le confessionnal' 'the devil in the confessional', démons de nos divisions, 'demons of our divisions' trinquer aux alentours, 'drinking to our neighbours' (positive). Whilst the nucleus of these phrases is in the image, the considerable sound-effects, usually a combination of assonance and alliteration can also be reproduced (but for cordiale virtualité). Further, it is arguable that an image relating to myth or history (e.g. aréopage) (rather than universal or local custom) which may be alive in the speaker's imagination but means nothing to the receptor, should be clarified. The words that most resist translation are those with sound-effect, and half-buried images such as la pagaille ('shambles'), outrecuidant 'overweening', micmac 'intrigues' all De Gaulle's phrases.

It is ironical that whilst translators often have most difficulty with pithy, colloquial, emotive, intensive figurative expressions that suddenly appear to give life to authoritative statements that are written to be spoken, it is usually inadvisable to 'convert' a literal SL to a figurative TL expression. In an authoritative statement, I do not think a sentence such as: L'Assemblée ne doit pas craindre de s'affirmer si elle veut renforcer son influence can be translated as 'The Assembly has to stick its neck out if it wants to heighten its impact', nor can die Preiserhöhungen beginnen wie erwartet $z u$ wirken become 'the price increases are beginning to bite, as expected', unless as compensation procedures for comparable SL figurative expressions in the near microcontext (Catford's cotext, 1965) which the translator has been compelled to render into literal language. If the above quotations were from an 'informative' but not authoritative statement, it would be legitimate to translate literal into figurative langulage, provided it is considered that the literal language is rather flabby and colourless, whilst the new figurative language is discreet and doesn't change the register too forcibly. I assume that whilst the first purpose of metaphor is to describe comprehensively, accurately and concisely, the second is to arouse interest, as in the conversion of humdrum sense to metaphor.

\section{$\mathbf{X}$}

Authoritative statements that are not written to be declaimed or read aloud present fewer problems for the translator since they are without the dimensions of gesture and visual expression (which may have to be accounted for in speeches as well as play translation - see Bassnett - McGuire (1980)) and they are likely to have fewer sound effects such as alliteration. They may of course be even more difficult for other reasons (culture, complex language), than speeches. The reader can study as well as read, and therefore the translation should be 
'semantic' without any concessions. I find Terence Killmartin's translation of De Gaulle's Memoirs (1971) unnecessarily paraphrastic :

La France vient du fond des âges.

France has emerged from the depths of the past.

Elle vit. Les siècles l'appellent.

She is a living entity. She responds to the call of the centuries.

Mais elle demeure elle-même au long du temps.

Yet she remains herself through time.

Ses limites peuvent se modifier sans

Her boundaries may alter, but not

que changent le relief, le climat, les fleuves

the contours, the climate, the rivers and

les mers, qui la marquent indéfiniment.

seas that are her eternal imprint.

Some of this is brilliant (e.g. 'but not the contours') but it seems to me that the translator has overemphasized, overexplicated, the notorious 'under-text'. I would not go beyond:

'France has come from the depth of the ages. She is alive. The centuries summon her. Yet she remains herself throughout time. Her boundaries may change, but not the contours, the climate, the rivers, the seas that are her indefinable mark.'

In a translation of this nature, aesthetic as well as semantic truth has to be respected, and the translation has if possible to follow the rhythms and emphases as well as the syntax of the original.

However, Killmartin has rightly seen that a change of syntax in the last sentence, also eliminating one of the synonyms se modifier and changer is desirable. His other sentences embroider the original unnecessarily. In the following sentences : $Y$ habitent des peuples - the stress can only be retained by a passive verb: 'Her land is inhabited by people...'. The French structure belongs to the written language, and has no English equivalent. The impact of syntax is as much at risk as that of metaphor in the translation of authoritative statements.

There are various other types of authoritative statements which need investigation from the point of view of translation theory. In the case of administrative and legal documents, an international treaty or law must be translated in accordance with a recognized convention agreed by both parties. The result normally looks like a literal translation (i.e. lexically, not so much grammatically) except for institutional terms, where there is a divergence between the common loan-translations (or through-translations) e.g., Convention sur le Plateau Continental 'Convention on the Continental Shelf' and the 'double' faux amis (deceptive cognates) like liberté syndicale et protection du droit syndical which is neither 'syndical freedom and protection of syndical law' nor "freedom of trade-unions and protection of trade-unions law" but "freedom of association and protection of the right to organize'. When the law of one country is translated into another, the translator may translate 'communicatively' or 'semantically', depending on the use to which the translation is to be put. In any 'seman- 
tic' translation, translation couplets, explanatory parentheses, glosses, etc., will be required, whilst a communicative translation relies on cultural equivalents.

I close my tentative examination of types of authoritative statements with a reference to philosophical works. Here I have already referred to the importance of precise translations of theme-words. Now if we look at the various theme words or slogans associated with Nietzsche - Wille zur Macht 'will to power'; ewige Wiederkunft 'eternal recurrence', gefährlich leben 'living dangerously'; Umwertung der Werte 'transvaluation of values' as well as the titles of the books - we note that there is not much difficulty in translating them. The main problem with Nietzsche, has usually been how literally or figuratively to interpret him : is his aggressiveness physical as well as intellectual? As he himself put it, the more one uses a metaphor, the more literally one begins to interpret it. One Nietzschan key-word, Übermensch, could be looked at again. All concepts begin as metaphors. This was translated as 'overman' until Shaw renamed it 'superman', where its connotations have always been misleading. If one looks at any of the German sources e.g., Ich lehre euch den Übermenschen. Der Mensch ist etwas, was überwunden werden soll. Was habt ihr getan, ihn zu überwinden?, it's clear to me that Nietzsche is not looking to an elitist superman to lead men, but that he regards Übermensch from its obnoxious associations.

Some other Nietzsche problems can only be solved by transcription : e.g., the double meaning of Sitten (cf. mœurs), customs or morals; the original meaning of schlecht (bad) as schlicht, plain, common, Schuld as 'guilt' and 'debt'; note too that English has still not got a satisfactory word for vieldeutig - ambiguous is wrong, 'multivocal' (Coleridge) is a dictionary fossil, 'polysemous' is the obvious word but still is not sufficiently current. Whether Nietzsche's Mitleid should always be translated as 'pity' - it is always a 'snarl' word in his writing - rather than 'compassion' or 'sympathy' is hard to say - certainly 'pity' with its association with pietà and piety brings out the Nietzsche weak Christian aspect.

I take it as axiomatic than in handling authoritative statements the translator has to empathize, to as fully as possible bring out the point of view of the writer. However, like the lexicographer, the translator can't be neutral. Like the lexicographer, he has to draw attention, separately, to all prejudiced senses in both articulations of meaning (word and sentence), where they are not clear or concealed. By 'prejudiced', I mean the sense of an expression that infringes the UN Universal Declaration of Human Rights. I see as much prejudice in the sentence: 'If instead of a Bethman-Hollweg we had a robuster man of the people, the heroic blood of the common grenadier would not have flowed in vain' as in 'it is a criminal lunacy to keep on drilling a born half-ape, i.e. a negro, until people think they have made a lawyer out of him' - both from the same text (Mein Kampf). (Manheim, 1972).

Within the text the translator's task is to render the original as objectively as he can, rigorously suppressing his own moral feelings. A text with which he 
passionately agrees must be treated similarly to a text with which he passionately disagrees. In his version of the body of an authoritative text, this remains the duty of the translator - he has to be accurate, to be "scientific", to disconnect his own feelings and the feelings of the TL readers, even though he is aware that a third reader, comparing the original with the translation, is always likely to find traces of his prejudices, however accurate the translation, since perfect objectivity can only be restricted to such general statements as $2+2=4$, which in itself of course is far from being valid in particular cases.

However, in his handling of authoritative texts, the translator has a responsibility to the moral and social truth, which he must exercise independently of his translation, viz. in an separate annotation. Where he believes it to be necessary he has to alert the TL reader to any explicit or latent expression of moral prejudice in the SL text, assuming that is (and it is some assumption), that he himself is committed to the kind of moral universals that are enshrined in the Constitutions, where they have one, of the countries influenced by the French Revolution.

To be concrete: 'blog' means 'non (British) Public School'; 'gook' means Vietnamese; 'wog' means Asian, 'Asiatic' means 'Asian', 'Chinaman' means 'Chinese', 'deficient' may mean 'mentally handicapped' etc. It is not enough to note, as dictionaries do, that such words are 'derogatory' or 'pejorative'. Further, I think the translator should gloss a statement such as 'I believe that Zionism is the worst form of racism and anti-human ideology our world has seen' with a separate comment such as: 'Israel has never had any extermination camps'. Such a comment is a fact and does not commit him to a belief in Zionism or Israel.

Secondly, I suggest that there are universal, cultural and personal elements in all expression, as well as metaphor. Cultural elements both in grammar (e.g. the male stone, the female plant in German) and metaphor (raining cats and dogs) are often the deposit of dead dogma. The value and insight of an original personal metaphor is to indicate a universal truth, to cut through cultural metaphor and this is why it must be literally translated:

Mai qui fut sans nuage et juin poignardé

'May that was cloudless and June that was stabbed' (Aragon)

Thirdly, regrettably, authoritative statements must reproduce any clichés, ancient idioms, stock metaphors, platitudes, proverbs appropriately in the translation. The translator's only standby here is to produce a slightly more outrageous version of such a detritus of language rather than the modified sense version often found in bilingual dictionaries e.g. : 'nitty-gritty' - as le fond du probleme (Collins - Robert), which changes the level of formality and warmth.

My last point, is that when faced with authoritative and official statements, it is the responsibility of the translator to translate: on the one hand, a Government should authorize official translations of its own most important institutions; is it to be Conseil d'Etat or Council of State? On the other hand, translators should not connive in importing words for objects which are not peculiar to a foreign culture, whilst theme-words and concept-words should not be im- 
ported at all. Admittedly the media often guided by commercial or snobbish interests, will as the fraudulent vox populi, have the last word and it's too late now to go back on détente and démarche, but the translator has as much responsibility for upholding the equality of languages and with it the equality of man, as anyone.

\section{BIBLIOGRAPHY}

BALDINGER, K. (1980) : Semantic Theory, Blackwell.

BASSNETT-MCGUIRE, S. (1980): Transiation Studies, Methuen.

CATFORD, J.C. (1965) : A Linguistic Theory of Translation, OUP.

DE GAULLE, C. (1970) : Mémoires d'espoir : le renouveau 1958-62, Plon.

DE GAULLE, C. (1971): Memoirs of Hope : Renewal (1958-62), Tr. T. Killmartin, Weidenfeld \& Nicholson.

HAYAKAWA, S.I. (1975) : Language in Thought and Action, N.Y. Harcourt, Brace.

KANT, I. (1956): Kritik der reinen Vernunft, Felix Meiner, Hamburg.

KANT, I. (1969) : Critique of Pure Reason, Tr. J. M. Meiklejohn. J. M. Dent \& Son, London.

KANT, I. (1974) : Critique of Pure Reason, Tr. Norman Kemp-Smith, Macmillan.

LANSON, G. (1957): Histoire de la littérature française, Hachette.

LEWIS, D. (1979): 'East German - a New Language?', GDR Monitor. No. 1, Univ. of Dundee.

MANHEIM, R. (1972) : Introduction to Hitler's Mein Kampf, ed. D.C. Watt, Hutchinson.

MATORÉ, G. (1953) : la Méthode en lexicographie, Didier, Paris.

NAESS, A.D. (1974): «Martin Heidegger» in Encyclopaedia Britannica, Vol. 8.

NEWMARK, P.P. (1981): Approaches to Translation, Pergamon.

O.E.C.D. (1969) : Refusal to Sell, Paris.

PASSERON, A. (1966) : De Gaulle parle 1962-66, Gayard.

PUTNAM, H. (1978) : 'Meaning, Reference and Stereotypes' in Translation and Meaning, ed. F. Guenthner and M. Guenthner-Reutter Duckworth.

RITCHIE, R.L.G. and SIMMONS, C.I. (1952) : Essays in Translation from French, C.U.P.

SKINNER, Q.S. (1980): 'Language and Social Change' in The State of the Language, ed. C. Michaels and C. Ricks. UCCA Press.

WEBER, M. (1978) : Selections in Translation. Tr. Eric Williams. Introduction W. G. Runciman, C.U.P. 